\title{
THE POLITICAL COMMUNICATION AS AN ESSENTIALLY CONTESTED CONCEPT
}

Key words

Political communication, politics, communication, essentially objectionable concept

Author

Aleksandar Vranješ, MA is a Teaching Assistant at the Faculty of Political Science of the University of Banja Luka

Correspondence

aleksandar.vranjes@fpn.unibl.org

Field

Political communication

\begin{abstract}
Summary
Referring to the thesis of "essentially contested concepts" which, according to Walter Gallie, are concepts that, despite their proper use, cause radical and lengthy discussions and unresolvable disagreements among those who use them. In this paper we build the thesis that political communication is essentially a contested concept. To prove this assertion, first we make an overview of different approaches to the concept of "politics" by showing how the term has changed over time and how it affected the various authors' determinations of definitions. Subsequently, referring to the term of "communication" and finally to the definition of "political communication", we demonstrated through the identification of the controversial elements that are commonly used in defining such concepts - that the basic thesis of this paper is true.
\end{abstract}

DOI

10.5937/pol1612142V

UDC

32.019.5:316.77

Paper received on

29.11.2016.

Paper accepted for publishing on

15.12.2016. 
More than sixty years ago British professor Walter Gallie published an essay entitled "Essentially contested concepts" in which he explained that many discussions on the subjects of politics, philosophy, art, religion and the like, cannot be resolved by arguments. It means that none of debate participants can prove that their approach is absolutely correct and utter, especially as people often assign different meanings to the same concepts.

Based on that, Gallie proposed category of "essentially contested concepts" that demonstrate an inability to define and interpret large numbers of categories in the humanities and social sciences to the level of axioms, or absolute truth. To support this thesis, through the domain of art, Gallie clarifies that the interlocutors quickly agree that oil on canvas is a "painting", but not is it a superb work of art, which in addition to expert assessment, requires subjective experience (Gallie, 1955: 167). Likewise, one of the examples is the famous attempt to formulate axioms in the field of communication science by the members of the "Palo Alto"1 group through the statement, "a man cannot but communicate". That they have failed to formulate the principle in the field of human communication is evident through many discussions on this subject, which have, more or less, successfully proved that the man can still - not communicate especially in unconsciousness states of biological or other external causes. In other words - communication as essential and debatable concept does not tolerate formulation attempts on the level of

\footnotetext{
${ }^{1}$ Researchers of the Institute of Mental Research in Palo Alto, California, in the fifties and sixties of the 20th century.
}

axioms, thus more complex than simple statements of the type "man is able to communicate" - and that finally, is not proposition to be proven, but the biological principle. In other words - to formulate a broad or frame definition of communication which would include this category in its totality by accepting Gallium approach - is an impossible task. Following the same principle, Galli discusses the concept of democracy, stressing that its meaning ultimately depends on the context and period when it is used. For definition to encompass the term as a whole, it would have to include meanings that democracy has held from ancient times to today - which is essentially impossible. Therefore, this kind of "semantic range" creates countless attempts to define this concept and endless discussions on the present topic. On the basis of these examples we notice yet another Gallium finding stating that complexity of these concepts leads to the challenge of searching for their definitions and therefore on the endless discussions that are reminiscent of competition, but without unprecedented and overall winner.

In this sense, for a certain concept to be categorized as "essentially contested" Galli holds that it should meet seven criteria by which one can assess its "controversy":

(1) Appraisive character Essentially contested concepts are, according to Gallie - usually overcrowded by values;

(2) Internal complexity - concept has to be coherent and designate a whole;

(3) Diverse describability - the meaning depends on which concept's constituent characteristics speaker assigns greater significance, or rather - on which 
of the concepts characteristics to put the emphasis;

(4) Openness - use of essentially contested concepts depends on the context - which is again, directly related to the historical period in which it is used. Changes in the concept's meaning over time are directly related to this feature;

(5) Reciprocal recognition - use of these concepts types is always aimed against a different definition, proposed meaning or the competitive use;

(6) The original exemplar Essentially contested concepts should be fixated to its generally accepted "roots of origin" that make the very concept;

(7) Progressive competition Gallie believes that in this process of "competition" or conflict of various defining attempts, it is almost impossible to achieve progress towards some form of consensus or mutual understanding of essentially disputed concept that we perceive differently. (Gallie, 1955: 172186).

Following this analogy, this paper is about the analysis of "political communication" concept which is constructed of two essentially contested concepts: politics and communication, and therefore it belongs to the same Gallie category. To corroborate this thesis we will first look at the complexity of the "politics" concept.

On the first pages of his book "The science of politics", Ljubomir Tadic reminds us that the term "politics" originates from the Greek word - "polis", which means the city-state of the ancient Greece. Further, the term "politeia" (Latin "politia") is derived in relation to the way of life and inner regulations of a human community or general public, or to a matter of all polis citizens. (Tadic, 2007: 19).

The same author in another book explains that politics is "the skill of running a city-state (polis), the skill of running a state and the skill of establishing relations toward other states". He also adds that this term refers to the activities of individuals or associations that influence citizens in order to satisfy particular interests (Tadic, 1996: 158). Therefore, the politics in ancient times implied a public matter, whose primary purpose was the common good and justice (there is no contradiction between politics and ethics), and as the ancient world had no concept of society, it follows that what we call social relations today, in ancient times was implied under the word "politics". It is important to mention that in the ancient world politics represented the realization of ideas in the community, primarily - the idea of the highest good - justice and general benefit. Political life is essentially active and practical life according to Aristotle - politics belongs to practical philosophy (Samardzic, 1993: 873). On the other hand, in the Ancient Rome, politics had only normative meaning - activity conducted only under certain points on normative assumptions (Ibid. 873). Finally, with decline of ancient civilizations politics lost its appropriate concept (Ibid. 875).

In the further analysis, Samardzic emphasizes that the Middle Ages completely nullified the ancient meaning of politics and instead of the previous separation of public and private spheres now there is a distinction between the secular and the spiritual. Therefore, one cannot speak about the existence of different spheres of life, because the worldly was literally subordinated to the spiritual, that is - life in general was subordinated to religion and state to the 
church (Ibid.). Thus, in the Middle Ages politics meant the rule (regnum), or the job of a monarch who was subordinate to the authority of the church. Since essentially public no longer existed, "public matters" disappeared from the medieval meaning of the term "politics".

With the advent of civil society (societas civilis) in European history comes a change in meaning of the "politics" concept. Tadic elaborates that the process of separation between society and state, between ethics and politics, led to the change in the meaning of the term "politics", particular as the focus broadens by techniques and instrumentalization of public life. That is illustrated in 'Leviathan" by Thomas Hobbs where policy (the state) is seen as a mechanism run by specific rules (Tadic, 1996, 159, 160).

Therefore appreciable are the changes in the concept of "politics". Regarding this, Samardzic rightly noted specified extension of meaning - from the original internal relations in "polis", to public activities at all levels of society - from local and regional to national, transnational, world, and global policy. Meaning is further expanded in recent decades and now we have, not just internal or foreign policy, but also economic, social, cultural, educational etc. politics, thus the very term lost its normative meaning (Samardzic, 1993: 873).

In his book "Politics, state and power" Nenad Kecmanovic explains the issues of defining the modern concept of politics by noting: "one associate politics with authoritarian allocation of living funds, the other to the state and the government, the third to the political conflicts and struggles and the fourth to the contrary, to prevention and peaceful settlement of internal and international conflicts through dialogue, concession, compromise and consensus "(Kecmanovic, 2010:16). Since the problem of defining the concept of politics has ideological and non-academic background, the author considers it logical that the definition of politics which legitimizes force, power and authority is more suited to strong states, i.e the definition that binds politics to dialogue is more suitable in the case of smaller and weaker countries (Ibid. 17).

Heywood defines politics in the broadest meaning, as an activity by which people create, maintain and modify general rules according they live by (Heywood 2004: 12). Therefore, the first concept's angle is from perspective of activities, but to avoid remaining completely ambiguous, Heywood adds that politics is indissolubly associated with a phenomena of conflict and cooperation, so the essence of politics is rather process in which different perspectives and opposed interests mutually reconcile with emphasis on pursuit of conflict resolution, rather than achieving the solution itself (Ibid. 12). Heywood is aware that this broader definition has certain drawbacks by enumerating different perspectives from which to observe this concept: the implementation of power, governance, collective decision-making, the allocation of scarce resources, committing fraud and manipulation, etc. (Ibid.13). For the same reason Heywood offers short recourse of politics observation from four perspectives:

(1) Politics as the art of governing - referring to Bismarck's identification of the essence of government with art, Heywood makes this link by identifying the authority as "legitimate power", separating the terms of authority and power insofar as the latter he defines as the ability to influence others behavior, 
while the government according to the author, is the right to do so;

(2) Politics as public affairs according to this point of view, the policy emerges from narrow framework of governance and it is positioned in the broader field of "public life" or "public affairs" with a focus on the activities of the state (or local community - note A.V.) in terms of regulating the socially important obligations that public institutions have toward society (or vice versa);

(3) The policy as an agreement and Consent - referring to the tag from the Bernard Crick's study entitled "In Defense of Politics" that says: "politics (is) the activity which satisfies different interests within the particular unit of power's frame, by giving part of the authority to its representatives in proportion to contribution of wealth and to survival of the entire community "(Crick, 1962. Heywood, 2004: 24). Heywood shifts the focus of defining the politics to the method of political decision making - the "art of possible", stressing that it is a mean of resolving the conflict through negotiations and where the objective is establishment of consensus not violence and use of force;

(4) Politics as power and distribution of resources - as the previous point of view is impossible to put into the context of one party or totalitarian states, Heywood also offers the last recourse in the wake of Adrian Leftwich, where politics is positioned in the center of collective social activities: formal and informal, public and private, between different people groups and institutions and societies. Respectively from each level of social interaction, family and nation to global level, politics is power of personified ability to achieve desired objective by any means, based on the "conflict" between human needs and desires that are normally limitless and existing and mostly of scarce resources to meet them on the other side (Heywood 2004: 14-26). These four approaches of defining the politics show additional complexity of this concept. Approach of Hannah Arendt is also very interesting. In her book "The Human Condition" (Arendt, 1958), she describes the policy as a noble and enlightened activity, arguing that politics is the most important form of human activity for the reason it involves relations between free and equal citizens respectively giving meaning to life. Of course this ideal-type approach to politics is hard to defend, especially in this model where we notice a social deviation - a fact that not all citizens are equal in one society. That is one of the conditions supposed be met in order for this thesis to be true - the existence of equal interlocutors, as Habermas described in his Theory of communicative action (Lyon, 2013: 18). Therefore, the thesis of Hannah Arendt is brought into question in regard to the equality of citizens participating in this noble and enlightened activity, because although formally and legally equal under the laws and constitutions, the inequalities among the citizens of a country are influenced by various factors: status, position, functions, financial status, level of education, etc. Also throughout the history we have seen that the artificial attempts to create equal citizens society usually ended up in formation of some of totalitarian states models.

How comprehensively difficult to define "politics" is evident from Samardzic's example of a corresponding lexical stratification in the English language which enables precise use of the 
concept of "politics", distinguishing form, process and content.

Therefore we have:

1) "Polity" - formal dimension of politics as a form (political system, institutional and normative assembly of the order itself, organization type and the like.);

2) "Politics" - constitutes a political processes dimension (the creation, expression, conflict and mediation of community interests, respectively the conflict resolution, interest representation and negotiations) whose integral parts are participants, procedures and public action itself;

3) "Policy" - the political content dimension that denotes politics as a specific decision making activity of all public life spheres (this is therefore the content side of the politics - the manner of public activities implementation, problem solving and instruments). (Samardzic, 1993: 873). In the Serbian language there are no similar lexical distinction. Samardzic believes it reflects conditions and preferences in science of politics that are still more concerned with political ideas and institutions rather than the decision-making processes and instruments (Ibid.).

Finally, to conclude this review with Maurice Duverger (1966.) who finds that since people think about politics, they are in two minds between diametrically opposed interpretations:

1) Politics as a struggle fundamentally represents the power of individuals and groups (that have seized it) to ensure benefits of dominance over society;

2) Politics as an effort to restore order and justice - the power that protects general interests and the common good from pressures of individual demands.

Therefore we conclude that firstly politics works to maintain minority privileges at the expense of majority, while later on it is a means to achieve integration of all individuals in the community and to create, as Aristotle stated, a "just state" (Duverger, 1966: 910).

Finally, Duverger is convinced that the true nature of politics, its essence and basic significance is reflected in the fact that it is always ambivalent, thus it contains both models that have mentioned, identifying politics with an image of the god Janus - the two faced god (Ibid.10). In other words, one society's organized power is always, at the same time, both a means of domination of a smaller group over a larger one and the means to ensure a certain social order where the ratio of one or the other element changes with respect to the epoch, conditions, social context, etc. (Ibid.). A complete overview of this can be seen as an argument about the essential controversy of the term politics that the following text will apply to the concept of "political communication".

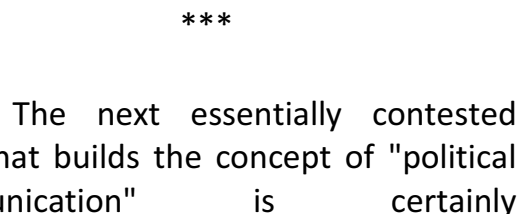
communication" is certainly communication. Radojkovic and Djordjevic claim that communication is a process of signs and symbols exchange that is initiated and participated in by, at least one, conscious entity (Radojkovic, Djordjevic, 2005: 22). Communication is also, in didactically motivated statements, determined as a human interaction of 
primary social importance, which can be realized by sharing information/messages, either directly or through mediums in a spatially and temporally specific psychosocial context with certain immediate effects and relatively permanent social consequences (Radojkovic Miletic, 2005: 28).

Régis Debray gives an interesting view of communication - the act divided into its spatial and temporal aspects. It is the flow of information within the same time-space sphere, while the other aspect describes the term as "transmission" signifying the transfer of information between different space-time spheres, including the dynamics of collective memory (Debray, 2000: 13). Debray's concept of "transmission" is definitely important for this paper, because it opens the possibility of observation of political communication from a discontinuous point in time. Of course, any of the definitions above cannot be, as in the case of politics, seen from the level of absolute truthfulness and comprehensiveness. It is an additional argument for the thesis of substantial controversy of political communication.

The roots of political communication can be seen in foundations of the first states, permeated through every pore of social communities, ranging from slaveholding to the present day. Slavujevic identifies the primal political communication through the actions of rulers in providing legitimacy to their authorities and emphasizing their country's size and power. Later we see the emergence of the aspirations of prominent citizens of democratic Athens or republican Rome to be elected to government positions or to win the assembly and opinions for their projects, or through examples of generals who raised combat morale of their troops. Throughout the ancient world thinkers assumed under "rhetoric" (especially political oratory), persuasion, coaxing, winning over, flattery, defamation, etc., in fact does not represent anything else but the roots of political communication (Slavujevic, 1997: 5). In other words political communication is a constitutive element of politics.

To be able to perceive the complexity of the concept of "political communication" we refer to its frequently cited definition - as a public debate regarding the allocation of public resources, government and civil sanctions, that Zoran Slavujevic (2009) takes as a "sample" describing all of the complexity of the concept - it is formed by combination of the multifaceted concept of communication and the complex activity/process of politics. Slavujevic begins the analysis of the aforementioned "sample" definition stating that the content of political communication are messages that can directly or indirectly relate to the constitution and exercise of power, but we also find examples of political communication content that are an exception to this claim. For example through a critique of authorities executed by organized citizens for the sake of resolving specific local community problem, but with no direct or indirect aim of changing the structure of government (Slavujevic, 2009 285, 22-26).

$$
\text { Public debate assumes }
$$

information exchange, which clearly implies that it is a two-way process. We have witnessed many examples of unidirectional political communication in the cases of political information and advertising, which are typically one-way communications without direct feedback. The definition that Slavujevic takes as a 
"sample" does not define political communication actors, respectively - who are the participants of public debate within the triangle: authority - the media the public. Frequently we encounter a definition that actors are politicians, journalists and citizens, but Slavujevic emphasizes that collective political entities are ignored, such as government bodies, political parties, NGOs, etc., respectively communication among them within organizations and institutions, between political representatives among themselves and within the audience of mass media (Ibid.). Also a problem in the determination of political communication as a public debate is the fact that this process takes place outside the conceived public sphere - secret conversations, interpersonal and group communicating, informal interviews, etc. are not taken into account. On the other hand, the definition includes verbal and written communication, but not non-verbal - what about the body language, visual communication or communication through political actions (protests, boycotts, strikes, etc.)? It is inconceivable to talk about political communication if we do not take into consideration the image of the political candidate, his behavior and style, the visual representation of his campaign, impressions based on billboards and similar advertisements.

Next comes the question of intent, or whether all the actors of political communication wish to participate in the process? The cited definition presupposes that in political communication all participants are actively engaged, ignoring messages referred to the passive consumers of media content or those that are influenced by the subconscious. Proceeding from the above, Slavujevic subdivided political communication into three phenomena: a function of the political process, specific activity and the scientific and educational activity (ibid.). Political communication as a function of the political process is very interesting to us and as such, Slavujevic defines it as a complex, dynamic and interactive process, focused on political actors and content, as well as system of communicational practices, procedures and processes of public and non-public messaging that are adapted to them and that are taking place between and within collective subjects. Thus, between both collective and individual and between individual subjects, that are subject to oral, written, visual, non-verbal communication, and communication by means of political actions, wherein communication may not be willing, but at least one of those involved must be aware of communication acts (Slavujevic, 2009: 25).

As much as we try to complete a single definition of the concept of political communication, it is easy to overlook certain important aspects of this process. Returning to the Debre's concept of transmission as exchange of information through time, we notice that in Slavujevic's definition this concept is omitted. Examples of political message transmission can be seen among cases such as neo-Nazism - to realize that Hitler's messages travel through time and still reach out to adherents of his ideology. The same case is a situation when cited words or phrases of history's great personalities have implications for political process in the present. All this can also be viewed as evidence for the claims of substantial controversy of the concept "political communication", which is specifically manifested through the attempt to define it. 
When we get back to the Gallie's (1955.) seven criteria we recognize that the concept of political communication can meet all the criteria that eventually makes it essentially contested. The more so, as we demonstrated substantial complexity and controversy of the very concept of policy, by concluding that the political communications is constitutive element of politics, and cannot be considered outside this context.

Based on this, we can review a couple of controversial elements that make "political communication" hard to define and present a real challenge for theorists who dare to give their definition of the concept:

1) The possibility that the citizens, as an integral part of the process of political communication are unaware of this. We can take the situation when a certain citizen is not interested in being a part of the community's political life, and yet through the media or social communication receives political messages and unconsciously builds his own political position as an example;

2) The policy by many authors is mostly seen as a process, and if we take politics as an activity, the definition should also include the work of public servants, spin doctors, consultants, advisors, informal circles, interest groups, lobbyists, etc.;

3) How, through definition of political communication, to include arcane sphere of politics - closed-door talks, negotiations, blackmails, threats, rewards, bribery and all that remains permanently out of public sight but is integral part of the political process;

4) Definitions often leave off global politics, international relations, diplomacy, the balance of power and geopolitics, but we are aware that communication is indispensable in all these;

5) How, by definition, to include non-political elements that have a direct implications on the political processes, especially in the times of conflict - the influence of big business and the military industry, technological development, the use of nuclear potential as an argument and so on? All these elements can be seen as repertoire of counter-arguments sent to the authors of definition of the "political communication", but for the purposes of this paper they are proof arguments of its basic premise.

\section{REFERENCES}

Arendt, H. (1958): The human condition, Chicago: University of Chicago Press

Gallie, W. B. (1955). Essentially contested concepts. Proceedings of the Aristotelian Society, Vol. 56, pp. 167-198.

Hejvud, E. (2004): Politika, Beograd: Klio

Debre, R. (2000): Uvod u mediologiju, Beograd: Klio

Diverže, M. (1966): Uvod u politiku, Beograd: Savremena administracija

Kecmanović, N. (2010): Politika, država i moć, Beograd: Fakultet političkih nauka, Čigoja štampa

Lyon, A. (2013): Deliberative Acts: Democracy, Rhetoric, and Rights, University Park, PA: Penn State University Press 
Radojković, M., Đorđević, T. (2001):

Osnovi komunikologije, Beograd: Fakultet političkih nauka

Radojković. M., Miletić, M. (2005):

Komuniciranje, mediji i društvo, Novi Sad:

Stilos

Samardžić, S. (1993): Politika, u: Matić, M., Podunavac, M.: „Enciklopedija političke kulture“, Beograd: Savremena administracija

Slavujević, Đ. Z. (2009): Političko komuniciranje, politička propaganda, politički marketing, Beograd: Grafokard

Slavujević, Z. (1997): Starovekovna propaganda: od Vavilonske kule do " Panem et circences", Beograd: Radnička štampa

Tadić, LJ. (2007): Javnost i retorika, Beograd: Zavod za udžbenike, Službeni glasnik

Tadić, LJ. (1996): Nauka o politici, Beograd:

BIGZ 


\section{ПОЛИТИЧКО КОМУНИЦИРАЊЕ КАО СУШТИНСКИ СПОРАН КОНЦЕПТ}

\begin{abstract}
Кључне ријечи
Политичко комуницирање, политика, комуникација, суштински спорни појмови

\section{Аутор}

Мр Александар Врањеш је виши асистент на Факултету политичких наука

Универзитета у Бањој Луци

Коресподенција

aleksandar.vranjes@fpn.unibl.org

Област
\end{abstract}

Политичко комуницирање

\section{Сажетак}

Позивајући се на тезу о "суштински спорним појмовима" који према Валтеру Галију представљају појмове који и поред правилне употребе изазивају неразрјешива неслагања међу онима који их користе, односно изазивају радикалне и дуготрајне расправе, у овом раду градимо тезу да је политичко комуницирање суштински споран концепт. Да бисмо доказали наведену тврдњу, прво правимо преглед различитих приступа појму "политика", показујући како се овај термин мијењао кроз вријеме и како је то утицало на одређивање дериниција код различитих аутора. Затим осврћући се на термин комуницирање и коначно дериниције самог политичког комуницирања, доказали смо да је основна теза овог рада тачна, кроз идентификацију спорних елемената који се обично користе приликом дефинисања овог концепта.

DOI

UDK 